\title{
Treatment Options of Macular Edema Secondary to Retinal Vein Occlusion (RVO): A Review
}

\author{
Aradhana Pokharel, Jie Luan \\ Department of Ophthalmology, Zhongda Hospital, Southeast University, Nanjing, China \\ Email: aradhana_s@hotmail.com, luanqiu10@163.com
}

How to cite this paper: Pokharel, A. and Luan, J. (2019) Treatment Options of Macular Edema Secondary to Retinal Vein Occlusion (RVO): A Review. Open Journal of Ophthalmology, 9, 70-83.

https://doi.org/10.4236/ojoph.2019.92009

Received: February 25, 2019

Accepted: April 12, 2019

Published: April 15, 2019

Copyright $\odot 2019$ by author(s) and Scientific Research Publishing Inc. This work is licensed under the Creative Commons Attribution International License (CC BY 4.0).

http://creativecommons.org/licenses/by/4.0/

\section{c) (i) Open Access}

\begin{abstract}
Retinal Vein Occlusion (RVO) is a common retinal vascular disease secondary to diabetic retinopathy resulting in permanent loss of vision despite available treatment options. Main vision impending complication of retinal vein occlusion is macular edema. Laser photocoagulation has been an established method for treating macular edema for many years but nowadays intravitreal injection of Anti-Vascular endothelial growth factors (Ranibizumab, Aflibercept Bevacizumab and Pegaptanib sodium) is the treatment of choice for macular edema from retinal vein occlusion. Intra-vitreal corticosteroids Triamcinolone Acetonide and Dexamethasone implant, are also being used to treat in some macular edema cases but with higher rates of side effects. Numerous surgical methods have been attempted for treating RVO and preventing macular edema; they include pars plana vitrectomy, radial optic neurotomy, laser induced chorioretinal anastomosis, and arteriovenous sheathotomy. Surgical methods supposedly relieve compression of the central retinal vein, altering the pathophysiology of vein occlusion at the level of the lamina cribrosa thus improving blood flow and oxygenation. But limitations result from its complications.
\end{abstract}

\section{Keywords}

Retinal Vein Occlusion, Macular Edema, Branch Retinal Vein Occlusion, Central Retinal Vein Occlusion, Vascular Endothelial Growth Factor

\section{Introduction}

Retinal Vein Occlusion (RVO) is the cause of the second most common retinal vascular disease after diabetic retinopathy resulting in potential irreversible loss of vision. Main vision impending complication of RVO is macular edema (ME). 
Types of RVO are: branch retinal vein occlusion (BRVO) and central retinal vein occlusion (CRVO). CRVO is occlusion of central retinal vein, and BRVO occlusion in branch retinal vein [1]. Hayreh divided RVO into 3 types: 1) BRVO divided into major BRVO and macular BRVO; 2) CRVO divided into ischemic (I-CRVO) and nonischemic (NI_CRVO); and 3) hemi-CRVO involving half of the retina and further divided into ischemic and nonischemic types [2]. According to a pooled analysis of population-based data, RVO prevalence in the USA, Europe, Asia, and Australia containing 68,751 individuals from 31 to 101 years of age was 5.20 per 1000 for any RVO, 4.42 per 1000 for BRVO, and 0.80 per 1000 for CRVO. It is suggested around 16.4 million people are affected by RVO (BRVO = 13.9 million and CRVO $=2.5$ million). BRVO is common than CRVO. Prevalence of RVO varied by ethnicity being highest in Hispanics and Asians and increased with age, but did not differ by gender [3]. Individuals with BRVO in 1 eye have a $10 \%$ risk of any RVO in the contra-lateral eye within 3 years. The estimated risk of contralateral involvement in people with CRVO is $\sim 1 \%$ per year, which increases to $7 \%$ at 5 years [1].

RVO pathogenesis (Figure 1) is multifactorial. RVO may be due to Virchow's triad: 1) hemodynamic changes (venous stasis), 2) degenerative changes of the vessel wall, and 3) blood hypercoagulability [5]. RVO may lead to fluid leak from capillaries draining into the obstructed vein, caused by secretion of VEGF and interleukin-6, and resulting in ME. [6]. Atherosclerosis is associated with RVO [7]. RVO can also be secondary to inflammation, vasospasm, or compression of retinal vessels [8]. RVO risk factors can be systemic and ophthalmic. Systemic risk includes DM, HTN, arteriosclerosis, vascular cerebral stroke, thrombophilia and blood hyperviscosity. Ophthalmic risk factors include glaucoma, ocular hypertension, decreased ocular perfusion pressure, with acquired and congenital retinal arteries changes. Hyperhomocysteinemia, factor V Leiden mutation and anti-cardiolipin antibodies also increase RVO risk. Vasculitis and Bechet disease may increase RVO risk [9].

CRVO patient may present with dense central scotoma or sudden painless monocular vision loss. Patient with BRVO may be asymptomatic, or complain of

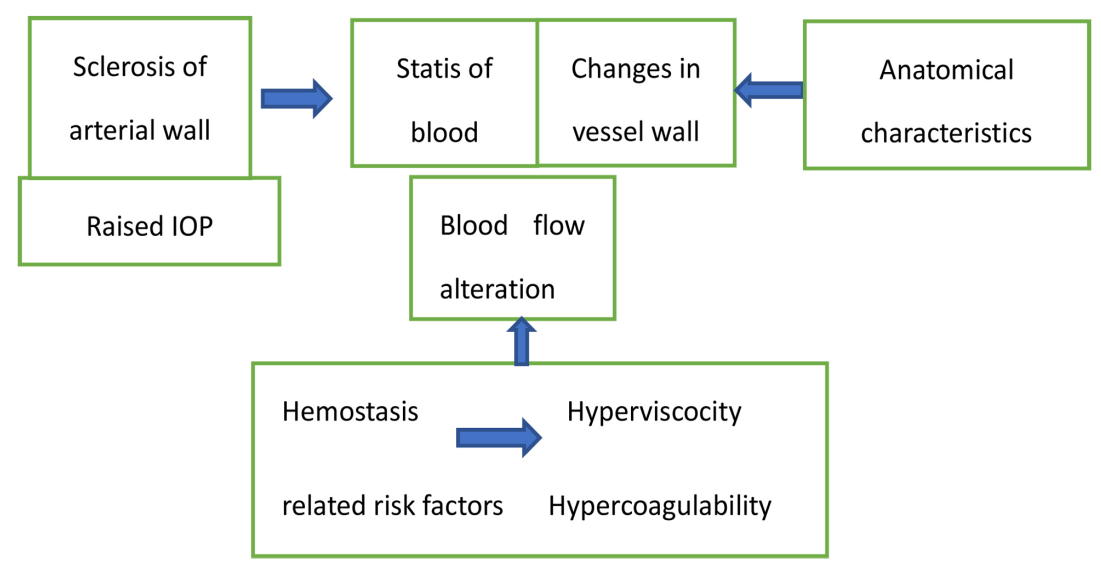

Figure 1. Pathogenesis of RVO [4]. 
relative scotoma, or metamorphopsia. I-CRVO presentation is acute [10]. Neovascularization, secondary to RVO, can develop in the iris (NVI), angle (NVA), optic nerve head, or retina. (NVE). NVA can compromise the aqueous humor outflow, resulting in neovascular glaucoma. Visual field defects and RAPD can be found. Studies by Hayreh 2015 [11] [12] showed fundus changes in RVO as retinal and sub-internal limiting membrane hemorrhages, and papilledema in I-CRVO, initially more marked in NI-CRVO. ME was more marked in I-CRVO and major BRVO than NI-CRVO and macular BRVO. I-CRVO had more retinal venous engorgement than NI-CRVO. FFA showed significant fluorescein leak, dilatation and obliteration of retinal capillary, and capillary foveal arcade breakage in I-CRVO than NI-CRVO. Neovascularization in retina and disc was seen only in major BRVO.

When RVO is suspected, proper history taking and clinical examinations should be done to find disease severity and start early treatment. Assessing Visual Acuity, Visual Field examination, Pupil examination, IOP, Color Doppler imaging of ocular blood vessels, slit lamp exam with undilated gonioscopy, and dilated fundoscopy to detect glaucoma, ocular neovascularization, and ME is necessary. OCT provides image of vitreomacular traction, retinal hole/detachments, ME and its thickness. FFA helps reveal delayed retinal venous filling, severity of retinal ischemia, retinal vascular leakage from retinal new vessels, or intraretinal pooling of the dye associated with ME [13]. Complete blood count, electrolytes, Lipid Profile, Blood Glucose level, ECG, Carotid Artery Doppler, BMI calculation, measuring Blood Pressure may help diagnosing systemic diseases. Management of RVO includes managing ME, treating associated risk factors and preventing neovascular complications.

\section{Mechanism of Macular Edema from RVO (Figure 2)}

Macular edema is characterized by fluid collection within the retina, due to the

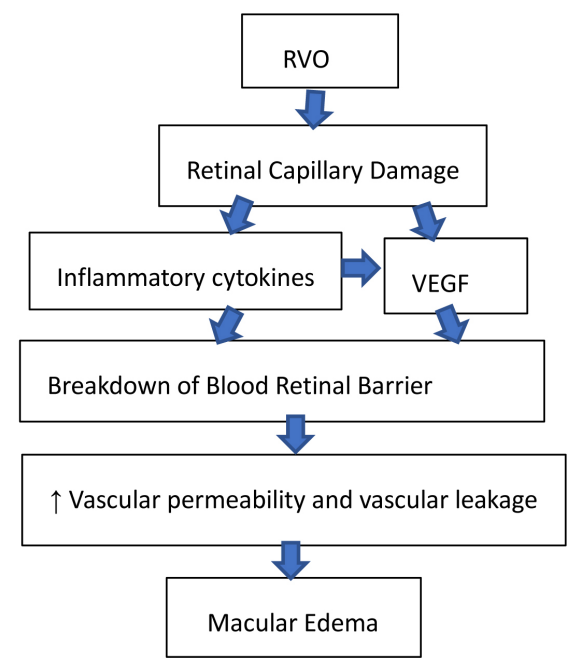

Figure 2. Mechanism of macular edema from retinal vein occlusion [14] [15] [16]. 
downregulation of the blood-retinal barrier and fluid leak from the vasculature. VEGF is proven to play crucial role in pathological process. VEGF expression is up-regulated by hypoxia and other stimuli. Intravitreal VEGF levels were noted to be elevated in patients with RVO [14] [15] [16]. Main complication of retinal vein occlusion is vision loss due to macular edema (Table 1 ).

\section{Treatment Options for ME Secondary to RVO}

Treatment of RVO focuses on treating its outcome rather than restoring normal venous circulation. Management of RVO includes managing ME, treating risk factors and preventing occurrence of NVI, NVA, NVE. Multiple clinical trials have been done in the past (Table 2) and more ongoing in present to find most suitable treatment options for macular edema. Nowadays intravitreal injection of anti-VEGF, Triamcinolone Acetonide and dexamethasone implant, are in priority to treat ME and other RVO's complications. Surgical anastomoses [18] and laser have been tried [19] to relieve the obstruction by using thrombolytic administration [20] and by passing the congestion via optic nerve sheathotomy [21] but, limitations results from its complications.

\subsection{Laser for ME}

Laser has been established method for treating RVO [22] [23]. Laser technique for resolving $\mathrm{ME}$ is macular grid photocoagulation while pan retinal (scatter) laser photocoagulation (PRPC) is used in treating retinal or disc neovascularization. Laser works by preventing secretion of chemical mediators originating from disturbed hemodynamics of retinal capillary and damaged tissue after RVO. The BVOS trial explored use of laser treatment for ME from BRVO reporting vision improvement in about $1 / 3$ of cases in first 3 months. Grid laser was considered after an FFA after 3 months in eyes with persistent ME and VA below 20/40. At 3 years endpoint, average of 1.33 lines was gained by treated eyes compared to 0.23 lines in control group. Since then, macular grid laser

Table 1. Vision loss mechanism in eyes with macular edema following retinal vein occlusion [17].

\begin{tabular}{|c|c|c|}
\hline Anatomical Disorder & $\begin{array}{l}\text { Pathological mechanism } \\
\text { reducing visual acuity }\end{array}$ & Reversibility \\
\hline $\begin{array}{l}\text { Impairment of the } \\
\text { photoreceptors in the fovea }\end{array}$ & $\begin{array}{l}\text { Disruption of the inner and/or outer } \\
\text { segments of photoreceptors }\end{array}$ & $\begin{array}{l}\text { Probably } \\
\text { irreversible }^{\star}\end{array}$ \\
\hline $\begin{array}{l}\text { Impairment of the neurons } \\
\text { in the inner retina }\end{array}$ & $\begin{array}{l}\text { Neuronal loss in either the inner nuclear layer } \\
\text { (INL) or the ganglion cell layer (GCL) due to } \\
\text { ischemia in the inner retina }\end{array}$ & Irreversible \\
\hline $\begin{array}{l}\text { Neuro-retinal swelling due } \\
\text { to macular edema }\end{array}$ & $\begin{array}{l}\text { Light scattering resulting in a reduced amount } \\
\text { of light received by photoreceptors at the fovea } \\
\text { Compromised neural transduction from } \\
\text { photoreceptors to inner retinal neurons }\end{array}$ & Reversible \\
\hline
\end{tabular}


Table 2. Clinical trials in treating ME from RVO.

\begin{tabular}{|c|c|c|c|c|c|}
\hline intervention & Study/author/year & RVO type & N0. of patients & Duration & Vision outcome \\
\hline $\begin{array}{c}\text { Laser } \\
\text { photocoagulation }\end{array}$ & BVOS Group 1984 [24] & BRVO & $\begin{array}{c}\text { Laser }=43 \\
\text { Control }=35\end{array}$ & 3 yrs. & $\begin{array}{l}\text { Laser: } 65 \% \text { gained } \geq 2 \text { line } \\
\text { Control: } 37 \% \text { gained } \geq 2 \text { line }\end{array}$ \\
\hline Ranibizumab & $\begin{array}{l}\text { BRAVOCampochiaro } \\
\text { et al., } 2010 \text { [43] } \\
\text { BRAVO Brown et al., } \\
2011[58]\end{array}$ & BRVO & $\begin{array}{c}\mathrm{RBZ} 0.5 \mathrm{mg}=131 \\
\mathrm{RBZ} 0.3 \mathrm{mg}=134 \\
\text { Control }=132\end{array}$ & $\begin{array}{l}1 \text { yr with } \\
\text { primary } \\
\text { endpoint at } \\
6 \mathrm{mo}\end{array}$ & $\begin{array}{c}\text { 6-mo outcomes: } R B Z 0.5 \mathrm{mg} \text { : } \\
+18.3 \text { letters; } 61.1 \% \text { gained } \geq 3 \\
\text { lines, RBZ } 0.3 \mathrm{mg}:+16.6 \\
\text { letters; } 55.2 \% \text { gained } \geq 3 \text { lines } \\
\text { Sham: }+7.3 \text { letters; } 28.8 \% \\
\text { gained } \geq 3 \text { lines }\end{array}$ \\
\hline Ranibizumab & $\begin{array}{l}\text { CRUISE } 2010 \text { Brown et al., } \\
2010[44]\end{array}$ & CRVO & $\begin{array}{c}\mathrm{RBZ} 0.5 \mathrm{mg}=130 \\
\mathrm{RBZ} 0.3 \mathrm{mg}=132 \\
\text { Control }=130\end{array}$ & $6 \mathrm{mo}$ & $\begin{array}{l}\text { 15-letter gain in } \sim 17 \%, 46 \%, \\
\text { and } 47 \% \text { in sham, } 0.3 \mathrm{mg} \text {, and } \\
0.5 \mathrm{mg} \text { ranibizumab groups, } \\
\text { respectively. }\end{array}$ \\
\hline Bevacizumab & $\begin{array}{l}\text { Epstein et al., } 2012 \\
{[40][41]}\end{array}$ & CRVO & $\begin{array}{l}\text { IVB } 2 \mathrm{mg}=30 \\
\text { Control }=30\end{array}$ & $6 \mathrm{mo}$ & $\begin{array}{l}\text { 15-letter gain in } 60 \% \text { of } \\
\text { bevacizumab vs. } \\
20 \% \text { of sham eyes }\end{array}$ \\
\hline Aflibercept & $\begin{array}{l}\text { VIBRANTCampochiaro } \\
\text { et al., } 2015 \text { [46] } \\
\text { VIBRANT Clark et al., } \\
2016[47]\end{array}$ & BRVO & $\begin{array}{l}\text { IAI } 2 \mathrm{mg}=91 \\
\quad \text { Laser }=92\end{array}$ & $\begin{array}{l}\text { 24-week } \\
\text { primary } \\
\text { endpoint, } 1 \\
\text { yr study }\end{array}$ & $\begin{array}{c}\text { 24-wk results: IAI: }+17.0 \\
\text { letters, } 52.7 \% \text { gained } \geq 3 \text { lines, } \\
\text { Laser: }+6.9 \text { letters, } 26.7 \% \\
\text { gained } \geq 3 \text { lines, } 52 \text {-wkresults: } \\
\text { IAI: }+17.1 \text { letters, } 57.1 \% \\
\text { gained } \geq 3 \text { lines, Laser/IAI: } \\
\quad+12.2 \text { letters, } 41.1 \% \\
\text { gained } \geq 3 \text { or more lines }\end{array}$ \\
\hline Aflibercept & $\begin{array}{l}\text { COPERNICUS Brown } \\
\text { et al., } 2013 \text { [48] }\end{array}$ & CRVO & $\begin{array}{l}\text { VTE } 2 \mathrm{mg}=115 \\
\text { Control }=74\end{array}$ & $6 \mathrm{mo}$ & $\begin{array}{c}15 \text {-letter gain in } 56 \% \text { of VTE } \\
\text { eyes vs. } 12 \% \text { sham }\end{array}$ \\
\hline Aflibercept & $\begin{array}{l}\text { GALILEO Korobelnik } \\
\text { et al., } 2013 \text { [49] }\end{array}$ & CRVO & $\begin{array}{l}\text { VTE } 2 \mathrm{mg}=106 \\
\text { Control }=71\end{array}$ & 52 weeks & $\begin{array}{c}\text { 15-letter gain in } 60 \% \text { of VTE } \\
\text { eyes vs. } 32.4 \% \text { in sham }\end{array}$ \\
\hline Pegaptanib sodium & $\begin{array}{l}\text { Wroblewski et al., } \\
\quad 2009[51]\end{array}$ & CRVO & $\begin{array}{l}\text { Pegaptanib } \\
0.3 \mathrm{mg}=33 \\
\text { Pegaptanib } \\
1.0 \mathrm{mg}=33 \\
\text { Control }=32\end{array}$ & 30 weeks & $\begin{array}{c}36 \% \text { and } 39 \% \text { of eyes treated } \\
\text { with } 0.3 \mathrm{mg} \text { and } 1 \mathrm{mg} \\
\text { pegaptanib gained } \geq 15 \\
\text { letters vs. } 28 \% \text { of sham }\end{array}$ \\
\hline \multirow[t]{2}{*}{$\begin{array}{l}\text { Triamcinolone } \\
\text { Acetonide }\end{array}$} & $\begin{array}{l}\text { SCORE Scott et al., } \\
\quad 2009[31]\end{array}$ & BRVO & $\begin{array}{l}\text { IVTA } 4 \mathrm{mg}=138 \\
\text { IVTA } 1 \mathrm{mg}=136 \\
\quad \text { Laser }=137\end{array}$ & $\begin{array}{l}\text { 12-mo } \\
\text { primary } \\
\text { endpoint } \\
36 \text { mo total }\end{array}$ & $\begin{array}{l}\text { IVTA } 4 \text { mg: }+4.0 \text { letters, } 27.2 \% \\
\text { gained } \geq 3 \text { Lines, IVTA } 1 \mathrm{mg:} \\
+5.7 \text { letters; } 25.6 \% \text { gained } \geq 3 \\
\text { lines Laser: }+4.2 \text { letters, } \\
28.9 \% \text { gained } \geq 3 \text { lines }\end{array}$ \\
\hline & SCORE Ip et al. 2009 [30] & CRVO & $\begin{array}{l}\text { Total }=271, \text { IVTA } 4 \\
\text { mg, } 1 \text { mg vs Control }\end{array}$ & $12 \mathrm{mo}$ & $\begin{array}{l}\text { 15-letter gain in } \sim 7 \%, 27 \% \text {, } \\
\text { and } 26 \% \text { for observation, } 1 \mathrm{mg} \text {, } \\
\text { and } 4 \mathrm{mg} \text { groups, respectively }\end{array}$ \\
\hline Dexamethasone & $\begin{array}{l}\text { GENEVA Haller et al., } \\
\quad 2010 \text { [34] [35] }\end{array}$ & $\begin{array}{l}\text { BRVO \& } \\
\text { CRVO }\end{array}$ & $\begin{array}{l}\text { DEX } 0.7 \mathrm{mg}=427 \\
\text { DEX } 0.35 \mathrm{mg}=414 \\
\text { Control }=426\end{array}$ & $6 \mathrm{mo}$ & $\begin{array}{c}\text { 15-letter gain in } 23 \%, 41 \% \text {, and } \\
40 \% \text { for observation, } 0.35 \mathrm{mg}, \\
\text { and } 0.7 \mathrm{mg} \text { DEX groups, } \\
\text { respectively }\end{array}$ \\
\hline
\end{tabular}

DEX = Dexamethasone implant, IVTA = Intra Vitreal Triamcinolone, IVB = Intra Vitreal Bevacizumab, RNZ = Ranibizumab, IAI = Intra Vitreal Aflibercept, VTE = VEGF Trap Eye. 
photocoagulation became gold standard for BRVO [24]. The central Vein occlusion group (CVOS) was planned to use laser for CRVO induced ME. It resulted in ME reduction but, no upgrade in visual acuity and final visual outcome was found compared to control group. Thus, observation became standard care for ME from CRVO [25]. Campochiaro in The RELATE Trial concluded that Scatter Photocoagulation does not reduce ME or treatment Burden in RVO eye [26]. Other study compared ranibizumab with standard grid laser for ME due to BRVO but found benefits in visual acuity gain and anatomic improvement with laser [27]. Some study say PRPC is not needed in NI-CRVO while a review [28] of 17 RCT concluded that though prophylactic PRPC did not prevent NVA/NVI or eliminated NVG risk for patient I-CRVO, it resulted in regression NVA/NVI and reduced progression to NVG. Today, intravitreal treatment has largely replaced laser as choice of intervention for RVO.

\subsection{Intravitreal Steroid for ME}

1) Triamcinolone Acetonide: is intermediate acting powerful steroid. It deadens the humoral and cell-mediated component of inflammatory process and decreases vessel permeability, resolving ME. It blocks breakdown of the blood ocular barrier by modulating effector proteins downstream of VEGF receptor [29]. The SCORE Study (Standard Care versus Corticosteroid for Retinal Vein Occlusion) compared patients with both BRVO and CRVO using 4 and $1 \mathrm{mg}$ of triamcinolone acetonide vs observation for 12 months [30] [31]. BRVO patient treated with 1 or $4 \mathrm{mg}$ of triamcinolone versus focal laser showed that all groups achieved visual acuity score of $\geq 15$ letters from baseline. In CRVO patient $7 \%$, $27 \%$, and $26 \%$ of participants achieved visual acuity score of $\geq 15$ letters in the observation, 1-mg, and 4-mg groups. The complication rates of cataracts and increased IOP were greater in the $4 \mathrm{mg}$ than $1 \mathrm{mg}$ group. Despite SCORE's result anti-VEGF has replaced corticosteroid as treatment choice for RVO because of side effects. High dose $20 \mathrm{mg}$ IVTA has been found to be safe and cost effective alternative to Anti-VEGF in treating ME from RVO in lower-middle-income countries despite high risk of cataract and IOP rise when weighed against the vision loss risk due to unaffordable anti-VEGF treatment [32].

2) Dexamethasone implant: (DEX implant; Ozurdex, Allergan) is a micronized, biodegradable dexamethasone releasing $700 \mathrm{mg}$ of dexamethasone over several months and is inserted into eye using 23-gauge needle. It was approved by FDA for RVO-associated ME in 2009. Dexamethasone has an anti-inflammatory action, including reduction in vascular permeability, inhibition of inflammatory cell migration, stabilization of the tight junctions of endothelial cells, and inhibition of VEGF synthesis, cytokines (IL-6, IL-8, MCP-1), and prostaglandins [33]. The GENEVA study (The Global Evaluation of implantable dexamethasone in RVO) a multicenter trials surveyed CRVO and BRVO patients treated with intravitreal DEX implant IVD $(0.7 \mathrm{mg}$ vs $0.35 \mathrm{mg})$ vs sham at day one and $0.7 \mathrm{mg}$ at open extension on day 180 [34] [35]. Study reported 
significant increase in VA from baseline in both DEX implant groups than sham from day $30-180$ with greatest response at day 60 . With no statistical difference in two DEX groups at any follow-up visit. Mean decrease in CST was significantly high with DEX implant $0.7 \mathrm{mg}(208 \pm 201 \mu \mathrm{m})$ and $0.35 \mathrm{mg}\left(177 \_ \pm 197\right.$ $\mu \mathrm{m})$ than with sham $(85 \pm 173 \mu \mathrm{m})$ at day 90 but not at day 180. An upgrade of $\geq 15$-letter in BCVA from baseline by $30 \%$ and $32 \%$ of patients after 60 days of first and second DEX implant. After second $0.7 \mathrm{mg}$ DEX implant the reduction in CST was similar to the first injection. Safety profile was also similar to the first treatment, except more cataract progression. The IOP increases were short-term and controlled by medication or observation. Cobalt study evaluated the effect of $0.7 \mathrm{mg}$ IVD $(\mathrm{n}=71)$ with $\mathrm{ME}<3$ month from BRVO. Retreatment was allowed $\geq 4$ months from the last injection. At 6 and 12 months, mean BCVA improvement was $18.6 \pm 12.9$ and $15.3 \pm 15.0$ letters, respectively. with maximum response (70\%) after 1 week. Over 12 -month period, $32 \%$ and $49 \%$ of patients received 1 and 3 injections, respectively, with a mean \pm SD interval of $20.0 \pm 5.0$ weeks. Patients requiring 3 injections had higher CRT and larger macular nonperfusion at baseline. Adverse events were increased IOP (35\%) and newly diagnosed cataract (16\%). Study concluded DEX implant with interval of $\geq 4$ months provides rapid and significantly better improvement in BCVA and CRT in BRVO-associated ME [36]. A study compared $4 \mathrm{mg}$ of IVTA $(\mathrm{n}=20)$ and 0.7 mg IVD $(n=20)$ for treating ME from NI-CRVO over 6 months. Study resulted that even patient achieving $\geq 15$ letters was $40 \%$ in both groups, IOP rise and cataract progression was 2.4 and 3.5 times higher respectively in IVTA than IVD. Thus concluding Intravitreal steroids to be effective in managing ME from RVO, while IVD being significantly safer than IVTA [37].

\subsection{Anti-VEGF}

Currently four anti-VEGF drugs are available to treat CRVO and BRVO. Ranibizumab and aflibercept are US FDA approved, while bevacizumab and pegaptanib sodium is an off-label drug. Anti-VEGF therapy is now the treatment of choice for RVO disease.

1) Bevacizumab: (Avastin) is humanized monoclonal antibody that binds all forms of VEGF-A. It is an effective off label anti-VEGF for treating ME due to RVO. It is also used in treating DR and ARMD [38] [39]. Epstein investigated efficacy and safety of bevacizumab in ME due to CRVO at randomized 6-month, double-masked clinical trial followed by a 6 -month open-label extension. At 6 months $60 \%$ and $20 \%$ in study and control group gained $\geq 15$ letters. BCVA improved by 14.1 letters in study group compared to decrease of 2 letters in control group. Mean decrease CRT was significantly greater in the study group $(426 \mu \mathrm{m})$ than control group $(102 \mu \mathrm{m})$ at all point up to week 24 . From month 6 , all patients received bevacizumab every 6 weeks for 6 months. At 12 month BCVA improved by 16.0 letters in the bevacizumab/bevacizumab (bz/bz) group and 4.6 letters in the sham/bevacizumab (sh/bz) group. $60 \%$ in (bz/bz) group gained $\geq 15$ 
letters compared to $33.3 \%$ in the (sh/bz) group. Mean decrease CRT was $435 \mu \mathrm{m}$ and $404 \mu \mathrm{m}$ in the bz/bz and sh/bz group respectively. Study concluded IVB given every 6 weeks for 12 months improves VA and reduce ME significantly, while delayed treatment may limit visual improvement. [40] [41]. A study evaluated 1-year efficacy and safety of low-frequency IVB in treating ME due RVO. Patients with CRVO $(\mathrm{n}=33)$ and BRVO $(\mathrm{n}=55)$ were included. After 1 month, BCVA and OCT were recorded. If $<30 \%$ improvement in BCVA and CMT, two injections were added at 1.5 -month intervals. others were injected as per need. After a year $74 \%$ had clinically significant improvement of BCVA $(>0.3 \log$ MAR) with 1.98 average number of injections. Both groups had clinically significant mean BCVA improvement from baseline vision and decrease in CMT. Pan retinal laser photocoagulation was done in $75.8 \%$ of all eyes with CRVO and sectoral photocoagulation in $49.1 \%$ of eyes with BRVO [42].

2) Ranibizumab: (Lucentis) is a monoclonal antibody fragment which binds all forms of VEGF. The BRAVO Study (Ranibizumab for the treatment of macular edema following BRVO) studied the Efficacy and Safety of Ranibizumab Injection in Patients with ME Secondary to BRVO. Study showed, 55\% patient receiving $0.3 \mathrm{mg}$ and $61 \%$ of patients receiving $0.5 \mathrm{mg}$ ranibizumab, achieved 3 -line vision improvement compared with $29 \%$ in the control group. Continued PRN treatment showed stabilizing vision, although laser was added in almost $50 \%$ of patients [43]. The CRUISE Trial (Ranibizumab for the treatment of macular edema after Central Retinal Vein Occlusion Study) studied Ranibizumab for treating ME from CRVO. 392 patients with ME secondary to CRVO were randomized to $0.3 \mathrm{mg}$ or $0.5 \mathrm{mg}$ of ranibizumab, or sham injection. At 6 months, $46 \%$ in $0.3 \mathrm{mg}$ group and $48 \%$ in $0.5 \mathrm{mg}$ group, showed improvement of 3 lines vision versus $17 \%$ in the control group [44]. Recently a study concluded no notable difference in outcome between IVR and IVB when treating ME from $\mathrm{RVO}$ for a year in routine clinical practice. This information might be of use in uplifting treatment burden of patient in the developing nations [45].

3) Aflibercept: Aflibercept (VEGF Trap-Eye) Intravitreal Aflibercept binds to VEGF-A, VEGF-B and placental growth factor (PIGF) and inhibits their activity with a higher affinity than ranibizumab. The VIBRANT trial evaluated efficacy of aflibercept over grid laser in patients with BRVO and ME. Patient received either Intravitreal Aflibercept (IAI) 2 mg every 4 weeks $(n=91)$ from baseline to week 20 or grid laser $(n=92)$ at baseline with single laser treatment if needed, from weeks 12 through 20. Eyes gaining $\geq 15$ ETDRS letters from baseline at week 24 was $52.7 \%$ in the IAI group compared with $26.7 \%$ in the laser group. At week 24 Mean improvement from baseline BCVA was 17.0 ETDRS letters in IAI group and 6.9 ETDRS letters in laser group while mean reduction in CRT was $280.5 \mu \mathrm{m}$ in IAI group and $128.0 \mu \mathrm{m}$ in laser group. 52-week result of VIBRANT study concluded that after 6 monthly IAI, injections every 8 weeks-maintained control of ME and visual benefits through week 52. In laser group, rescue IAI given after 24 week produced solid vision improvement at week 52 [46] [47]. The COPERNICUS study and The GALILEO study both evaluated safety and ef- 
ficacy of IAI in treating ME from CRVO. After one year Over 50\% of treated eyes gained $\geq 15$ ETDRS letters from baseline in both studies [48] [49]. A study Compared Efficacy of Intravitreal Aflibercept and Bevacizumab for ME due to BRVO. For 12 months patients $(n=27)$ received PRN IVB or $(n=25)$ PRN IAI with monthly follow-ups. Around $2 / 3$ of the patients in both groups had final BCVA $\geq 20 / 40$ and visual gains $>3$ lines from baseline to month 12. Mean number of aflibercept and bevacizumab injection was 2.12 and 2.22 during period of 12-month. Both IAI and IVB were effective in reducing macular thickness and improving visual acuity [50].

4) Pegaptanib sodium: (Macugen) is a selective antagonist binding to 165 isoforms of VEGF. For ME from CRVO Wroblewski et al. reported, double-masked phase two trial. Patients with CRVO for $\leq 6$ months were randomly assigned $(1: 1: 1)$ to injection of pegaptanib $(\mathrm{n}=33) 1 \mathrm{mg}$ and $0.3 \mathrm{mg}$, or sham $(\mathrm{n}=32)$ every 6 weeks for 24 weeks. At 30 weeks eyes gaining $\geq 15$ letters among treatment groups was not significantly different. Study concluded pegaptanib appears to provide both visual and anatomical benefits in the treating ME from CRVO. Wroblewski et al. also (level II) assessed use of pegaptanib sodium for ME from BRVO. Subjects received pegaptanib $0.3 \mathrm{mg}(\mathrm{n}=15)$ and $1 \mathrm{mg}(\mathrm{n}=5)$ at baseline and at weeks 6 and 12 with subsequent injections at 6 -week intervals up to 48 weeks. Both groups had similar outcomes from baseline to week 54 in mean BCVA $(+14 \pm 13$ letters $)$ and central subfield thickness $(-201 \pm 153 \mu \mathrm{m})$ [51] [52].

\section{Surgical and Other Treatments}

Numerous surgical methods have been attempted for treating RVO. Treatments include pars plana vitrectomy (PPV) with or without internal limiting membrane (ILM) peeling, radial optic neurotomy (RON), and laser induced chorioretinal anastomosis (LCA), tissue plasminogen activator (tPA) and arteriovenous sheathotomy. These methods supposedly relieve compression of the central retinal vein, altering the pathophysiology of RVO at the level of the lamina cribrosa (RON) or by improving blood flow and oxygenation (PPV, LCA) [53] [54]. Some studies [55] show LMWH role in the acute treatment of RVO while other study [56] shows Parnaparin to be more effective than aspirin in preventing functional worsening in RVO. Study by Hayreh [57] showed use of aspirin, other anti-platelet aggregating agents, or anticoagulants in patients with CRVO and hemi-CRVO was associated with a worse visual outcome and no credible benefit. Case reports of patients treated with clopidogrel, tPA (both intravitreal and into a vein), heparin, aspirin, LMWH, or hemodilution, have shown variable results. But none of the treatment methods has shown to prevent the vision loss from RVO and larger clinical trial allowing a guidance is required.

\section{Summary}

Today RVO is a prevalent disease of retinal vessels secondary to diabetic retino- 
pathy. The main complication of retinal vein occlusion is vision loss due to macular edema. Anti-VEGF therapy is the current standard of care for treating ME due to less side effect profile than intravitreal steroids which has a higher incidence of increased intraocular pressure and cataract formation. Future awaits more effective single or combined treatments for macular edema while minimizing health care cost.

\section{Conflicts of Interest}

The authors declare no conflicts of interest regarding the publication of this paper.

\section{References}

[1] Hayreh, S.S., Zimmerman, M.B. and Podhajsky, P. (1994) Incidence of Various Types of Retinal Vein Occlusion and Their Recurrence and Demographic Characteristics. American Journal of Ophthalmology, 117, 429-441. https://doi.org/10.1016/S0002-9394(14)70001-7

[2] Hayreh, S.S. (2005) Prevalent Misconceptions about Acute Retinal Vascular Occlusive Disorders. Progress in Retinal and Eye Research, 24, 493-519. https://doi.org/10.1016/j.preteyeres.2004.12.001

[3] Rogers, S., McIntosh, R.L., Cheung, N., Lim, L., Wang, J.J., Mitchell, P., et al. (2010) The Prevalence of Retinal Vein Occlusion: Pooled Data from Population Studies from the United States, Europe, Asia, and Australia. Ophthalmology, 117, 313-319e1.

[4] Marcucci, R., Sofi, F., Grifoni, E., Sodi, A. and Prisco, D. (2011) Retinal Vein Occlusions: A Review for the Internist. Internal and Emergency Medicine, 6, 307-314. https://doi.org/10.1007/s11739-010-0478-2

[5] Zhou, J.Q., Xu, L., Wang, S., Wang, Y.X., You, Q.S., Tu, Y., et al. (2013) The 10-Year Incidence and Risk Factors of Retinal Vein Occlusion: The Beijing Eye Study. Ophthalmology, 120, 803-808. https://doi.org/10.1016/j.ophtha.2012.09.033

[6] Glanville, J., Patterson, J., McCool, R., Ferreira, A., Gairy, K. and Pearce, I. (2014) Efficacy and Safety of Widely Used Treatments for Macular Oedema Secondary to Retinal Vein Occlusion: A Systematic Review. BMC Ophthalmology, 14, 7. https://doi.org/10.1186/1471-2415-14-7

[7] O'Mahoney, P.R., Wong, D.T. and Ray, J.G. (2008) Retinal Vein Occlusion and Traditional Risk Factors for Atherosclerosis. Archives of Ophthalmology, 126, 692-699. https://doi.org/10.1001/archopht.126.5.692

[8] Yen, Y.C., Weng, S.F., Chen, H.A. and Lin, Y.S. (2013) Risk of Retinal Vein Occlusion in Patients with Systemic Lupus Erythematosus: A Population-Based Cohort Study. The British Journal of Ophthalmology, 97, 1192-1196. https://doi.org/10.1136/bjophthalmol-2013-303265

[9] Kolar, P. (2014) Risk Factors for Central and Branch Retinal Vein Occlusion: A Meta-Analysis of Published Clinical Data. Journal of Ophthalmology, 2014, Article ID: 724780. https://doi.org/10.1155/2014/724780

[10] Khayat, M., Williams, M. and Lois, N. (2018) Ischemic Retinal Vein Occlusion: Characterizing the More Severe Spectrum of Retinal Vein Occlusion. Survey of Ophthalmology, 63, 816-850. https://doi.org/10.1016/j.survophthal.2018.04.005

[11] Hayreh, S.S. and Zimmerman, M.B. (2015) Fundus Changes in Branch Retinal Vein 
Occlusion. Retina, 35, 1016-1027. https://doi.org/10.1097/IAE.0000000000000418

[12] Hayreh, S.S. and Zimmerman, M.B. (2015) Fundus Changes in Central Retinal Vein Occlusion. Retina, 35, 29-42. https://doi.org/10.1097/IAE.0000000000000256

[13] Sivaprasad, S., Amoaku, W.M., Hykin, P. and RVO Guideline Group (2015) The Royal College of Ophthalmologists Guidelines on Retinal Vein Occlusions: Executive Summary. Eye, 29, 1633-1638. https://doi.org/10.1038/eye.2015.164

[14] Vinores, S.A., Derevjanik, N.L., Ozaki, H., Okamoto, N. and Campochiaro, P.A. (1999) Cellular Mechanisms of Blood-Retinal Barrier Dysfunction in Macular Edema. Documenta Ophthalmologica, 97, 217-228. https://doi.org/10.1023/A:1002136712070

[15] Aiello, L.P., Avery, R.L., Arrigg, P.G., Keyt, B.A., Jampel, H.D., Shah, S.T., et al. (1994) Vascular Endothelial Growth Factor in Ocular Fluid of Patients with Diabetic Retinopathy and Other Retinal Disorders. The New England Journal of Medicine, 331, 1480-1487. https://doi.org/10.1056/NEJM199412013312203

[16] Boyd, S.R., Zachary, I., Chakravarthy, U., Allen, G.J., Wisdom, G.B., Cree, I.A., et al. (2002) Correlation of Increased Vascular Endothelial Growth Factor with Neovascularization and Permeability in Ischemic Central Vein Occlusion. Archives of Ophthalmology, 120, 1644-1650. https://doi.org/10.1001/archopht.120.12.1644

[17] Iijima, H. (2018) Mechanisms of Vision Loss in Eyes with Macular Edema Associated with Retinal Vein Occlusion. Japanese Journal of Ophthalmology, 62, 265-273. https://doi.org/10.1007/s10384-018-0586-5

[18] Fekrat, S. and de Juan Jr., E. (1999) Chorioretinal Venous Anastomosis for Central Retinal Vein Occlusion: Transvitreal Venipuncture. Ophthalmic Surgery and Lasers, 30, 52-55.

[19] McAllister, I.L., Gillies, M.E., Smithies, L.A., Rochtchina, E., Harper, C.A., Daniell, M.D., et al. (2010) The Central Retinal Vein Bypass Study: A Trial of Laser-Induced Chorioretinal Venous Anastomosis for Central Retinal Vein Occlusion. Ophthalmology, 117, 954-965. https://doi.org/10.1016/j.ophtha.2009.10.026

[20] Feltgen, N., Junker, B., Agostini, H. and Hansen, L.L. (2007) Retinal Endovascular Lysis in Ischemic Central Retinal Vein Occlusion: One-Year Results of a Pilot Study. Ophthalmology, 114, 716-723.e1. https://doi.org/10.1016/j.ophtha.2006.06.064

[21] Arevalo, J.F., Garcia, R.A., Wu, L., Rodriguez, F.J., Dalma-Weiszhausz, J., Quiroz-Mercado, H., et al. (2008) Radial Optic Neurotomy for Central Retinal Vein Occlusion: Results of the Pan-American Collaborative Retina Study Group (PACORES). Retina, 28, 1044-1052. https://doi.org/10.1097/IAE.0b013e3181744153

[22] McIntosh, R.L., Mohamed, Q., Saw, S.M. and Wong, T.Y. (2007) Interventions for Branch Retinal Vein Occlusion: An Evidence-Based Systematic Review. Ophthalmology, 114, 835-854. https://doi.org/10.1016/j.ophtha.2007.01.010

[23] Mohamed, Q., McIntosh, R.L., Saw, S.M. and Wong, T.Y. (2007) Interventions for Central Retinal Vein Occlusion: An Evidence-Based Systematic Review. Ophthalmology, 114, 507-519. https://doi.org/10.1016/j.ophtha.2006.11.011

[24] The Branch Vein Occlusion Study Group (1984) Argon Laser Photocoagulation for Macular Edema in Branch Vein Occlusion. American Journal of Ophthalmology, 98, 271-282. https://doi.org/10.1016/0002-9394(84)90316-7

[25] (1993) Central Vein Occlusion Study of Photocoagulation Therapy. Baseline Findings. Central Vein Occlusion Study Group. The Online Journal of Current Clinical Trials, No. 95.

[26] Campochiaro, P.A., Hafiz, G., Mir, T.A., Scott, A.W., Solomon, S., Zimmer-Galler, 
I., et al. (2015) Scatter Photocoagulation Does Not Reduce Macular Edema or Treatment Burden in Patients with Retinal Vein Occlusion: The RELATE Trial. Ophthalmology, 122, 1426-1437. https://doi.org/10.1016/j.ophtha.2015.04.006

[27] Tan, M.H., McAllister, I.L., Gillies, M.E., Verma, N., Banerjee, G., Smithies, L.A., et al. (2014) Randomized Controlled Trial of Intravitreal Ranibizumab versus Standard Grid Laser for Macular Edema Following Branch Retinal Vein Occlusion. American Journal of Ophthalmology, 157, 237-247e1.

[28] Rehak, M. and Wiedemann, P. (2010) Retinal Vein Thrombosis: Pathogenesis and Management. Journal of Thrombosis and Haemostasis. JTH, 8, 1886-1894. https://doi.org/10.1111/j.1538-7836.2010.03909.x

[29] Edelman, J.L., Lutz, D. and Castro, M.R. (2005) Corticosteroids Inhibit VEGF-Induced Vascular Leakage in a Rabbit Model of Blood-Retinal and Blood-Aqueous Barrier Breakdown. Experimental Eye Research, 80, 249-258. https://doi.org/10.1016/j.exer.2004.09.013

[30] Ip, M.S., Scott, I.U., VanVeldhuisen, P.C., Oden, N.L., Blodi, B.A., Fisher, M., et al. (2009) A Randomized Trial Comparing the Efficacy and Safety of Intravitreal Triamcinolone with Observation to Treat Vision Loss Associated with Macular Edema Secondary to Central Retinal Vein Occlusion: The Standard Care vs Corticosteroid for Retinal Vein Occlusion (SCORE) Study Report 5. Archives of Ophthalmology, 127, 1101-1114. https://doi.org/10.1001/archophthalmol.2009.234

[31] Scott, I.U., Ip, M.S., VanVeldhuisen, P.C., Oden, N.L., Blodi, B.A., Fisher, M., et al. (2009) A Randomized Trial Comparing the Efficacy and Safety of Intravitreal Triamcinolone with Standard Care to Treat Vision Loss Associated with Macular Edema Secondary to Branch Retinal Vein Occlusion: The Standard Care vs Corticosteroid for Retinal Vein Occlusion (SCORE) Study Report 6. Archives of Ophthalmology, 127, 1115-1128. https://doi.org/10.1001/archophthalmol.2009.233

[32] Ghoraba, H.H., Leila, M., Elgouhary, S.M., Elgemai, E.E.M., Abdelfattah, H.M., Ghoraba, H.H., et al. (2018) Safety of High-Dose Intravitreal Triamcinolone Acetonide as Low-Cost Alternative to Anti-Vascular Endothelial Growth Factor Agents in Lower-Middle-Income Countries. Clinical Ophthalmology, 2018, 2383-2391. https://doi.org/10.2147/OPTH.S185274

[33] Felinski, E.A. and Antonetti, D.A. (2005) Glucocorticoid Regulation of Endothelial Cell Tight Junction Gene Expression: Novel Treatments for Diabetic Retinopathy. Current Eye Research, 30, 949-957. https://doi.org/10.1080/02713680500263598

[34] Haller, J.A., Bandello, F., Belfort Jr., R., Blumenkranz, M.S., Gillies, M., Heier, J., et al. (2010) Randomized, Sham-Controlled Trial of Dexamethasone Intravitreal Implant in Patients with Macular Edema Due to Retinal Vein Occlusion. Ophthalmology, 117, 1134-1146e3.

[35] Haller, J.A., Bandello, F., Belfort Jr., R., Blumenkranz, M.S., Gillies, M., Heier, J., et al. (2011) Dexamethasone Intravitreal Implant in Patients with Macular Edema Related to Branch or Central Retinal Vein Occlusion Twelve-Month Study Results. Ophthalmology, 118, 2453-2460. https://doi.org/10.1016/j.ophtha.2011.05.014

[36] Yoon, Y.H., Kim, J.W., Lee, J.Y., Kim, I.T., Kang, S.W., Yu, H.G., et al. (2018) Dexamethasone Intravitreal Implant for Early Treatment and Retreatment of Macular Edema Related to Branch Retinal Vein Occlusion: The Multicenter COBALT Study. Ophthalmologica, 240, 81-89. https://doi.org/10.1159/000487547

[37] Mishra, S.K., Gupta, A., Patyal, S., Kumar, S., Raji, K., Singh, A., et al. (2018) Intravitreal Dexamethasone Implant versus Triamcinolone Acetonide for Macular Oedema of Central Retinal Vein Occlusion: Quantifying Efficacy and Safety. International Journal of Retina and Vitreous, 4, 13. 
https://doi.org/10.1186/s40942-018-0114-2

[38] Yilmaz, T. and Cordero-Coma, M. (2012) Use of Bevacizumab for Macular Edema Secondary to Branch Retinal Vein Occlusion: A Systematic Review. Graefés Archive for Clinical and Experimental Ophthalmology, 250, 787-793. https://doi.org/10.1007/s00417-012-2016-6

[39] Hoeh, A.E., Ruppenstein, M., Ach, T. and Dithmar, S. (2010) OCT Patterns of Macular Edema and Response to Bevacizumab Therapy in Retinal Vein Occlusion. Graefe's Archive for Clinical and Experimental Ophthalmology, 248, 1567-1572. https://doi.org/10.1007/s00417-010-1419-5

[40] Epstein, D.L., Algvere, P.V., von Wendt, G., Seregard, S. and Kvanta, A. (2012) Bevacizumab for Macular Edema in Central Retinal Vein Occlusion: A Prospective, Randomized, Double-Masked Clinical Study. Ophthalmology, 119, 1184-1189. https://doi.org/10.1016/j.ophtha.2012.01.022

[41] Epstein, D.L., Algvere, P.V., von Wendt, G., Seregard, S. and Kvanta, A. (2012) Benefit from Bevacizumab for Macular Edema in Central Retinal Vein Occlusion: Twelve-Month Results of a Prospective, Randomized Study. Ophthalmology, 119, 2587-2591. https://doi.org/10.1016/j.ophtha.2012.06.037

[42] Ivanovska Adjievska, B., Boskurt, S., Orovcanec, N. and Dimovska-Jordanova, V. (2017) The Outcome of Low-Frequency Intravitreal Bevacizumab Therapy for Macular Edema in Retinal Vein Occlusions. Clinical Ophthalmology, 2017, 1183-1190. https://doi.org/10.2147/OPTH.S137380

[43] Campochiaro, P.A., Heier, J.S., Feiner, L., Gray, S., Saroj, N., Rundle, A.C., et al. (2010) Ranibizumab for Macular Edema Following Branch Retinal Vein Occlusion: Six-Month Primary End Point Results of a Phase III Study. Ophthalmology, 117, 1102-1112e1.

[44] Brown, D.M., Campochiaro, P.A., Singh, R.P., Li, Z., Gray, S., Saroj, N., et al. (2010) Ranibizumab for Macular Edema Following Central Retinal Vein Occlusion: Six-Month Primary End Point Results of a Phase III Study. Ophthalmology, 117, 1124-1133e1.

[45] Khan, M., Wai, K.M., Silva, F., Srivastava, S., Ehlers, J., Rachitskaya, A., Babiuch, A., Deasy, R., Kaiser, P., Schachat, A., Yuan, A. and Singh, R. (2017) Comparison of Ranibizumab and Bevacizumab for Macular Edema Secondary to Retinal Vein Occlusions in Routine Clinical Practice. Ophthalmic Surgery, Lasers and Imaging Retina, 48, 465-472. https://doi.org/10.3928/23258160-20170601-04

[46] Campochiaro, P.A., Clark, W.L., Boyer, D.S., Heier, J.S., Brown, D.M., Vitti, R., et al. (2015) Intravitreal Aflibercept for Macular Edema Following Branch Retinal Vein Occlusion: The 24-Week Results of the VIBRANT Study. Ophthalmology, 122, 538-544. https://doi.org/10.1016/j.ophtha.2014.08.031

[47] Clark, W.L., Boyer, D.S., Heier, J.S., Brown, D.M., Haller, J.A., Vitti, R., et al. (2016) Intravitreal Aflibercept for Macular Edema Following Branch Retinal Vein Occlusion: 52-Week Results of the VIBRANT Study. Ophthalmology, 123, 330-336. https://doi.org/10.1016/j.ophtha.2015.09.035

[48] Brown, D.M., Heier, J.S., Clark, W.L., Boyer, D.S., Vitti, R., Berliner, A.J., et al. (2013) Intravitreal Aflibercept Injection for Macular Edema Secondary to Central Retinal Vein Occlusion: 1-Year Results from the Phase 3 COPERNICUS Study. American Journal of Ophthalmology, 155, 429-437e7.

[49] Korobelnik, J.F., Holz, F.G., Roider, J., Ogura, Y., Simader, C., Schmidt-Erfurth, U., et al. (2014) Intravitreal Aflibercept Injection for Macular Edema Resulting from Central Retinal Vein Occlusion: One-Year Results of the Phase 3 GALILEO Study. 
Ophthalmology, 121, 202-208. https://doi.org/10.1016/j.ophtha.2013.08.012

[50] Wang, J.K., Su, P.Y., Hsu, Y.R., Chen, Y.J., Chen, F.T. and Tseng, Y.Y. (2016) Comparison of the Efficacy of Intravitreal Aflibercept and Bevacizumab for Macular Edema Secondary to Branch Retinal Vein Occlusion. Journal of Ophthalmology, 2016, Article ID: 8421940. https://doi.org/10.1155/2016/8421940

[51] Wroblewski, J.J., Wells 3rd, J.A., Adamis, A.P., Buggage, R.R., Cunningham Jr., E.T., Goldbaum, M., et al. (2009) Pegaptanib Sodium for Macular Edema Secondary to Central Retinal Vein Occlusion. Archives of Ophthalmology, 127, 374-380. https://doi.org/10.1001/archophthalmol.2009.14

[52] Wroblewski, J.J., Wells III, J.A. and Gonzales, C.R. (2010) Pegaptanib Sodium for Macular Edema Secondary to Branch Retinal Vein Occlusion. American Journal of Ophthalmology, 149, 147-154. https://doi.org/10.1016/j.ajo.2009.08.005

[53] Yeh, S., Kim, S.J., Ho, A.C., Schoenberger, S.D., Bakri, S.J., Ehlers, J.P., et al. (2015) Therapies for Macular Edema Associated with Central Retinal Vein Occlusion: A Report by the American Academy of Ophthalmology. Ophthalmology, 122, 769-778. https://doi.org/10.1016/j.ophtha.2014.10.013

[54] Ehlers, J.P., Kim, S.J., Yeh, S., Thorne, J.E., Mruthyunjaya, P., Schoenberger, S.D., et al. (2017) Therapies for Macular Edema Associated with Branch Retinal Vein Occlusion: A Report by the American Academy of Ophthalmology. Ophthalmology, 124, 1412-1123. https://doi.org/10.1016/j.ophtha.2017.03.060

[55] Squizzato, A., Manfredi, E., Bozzato, S., Dentali, F. and Ageno, W. (2010) Antithrombotic and Fibrinolytic Drugs for Retinal Vein Occlusion: A Systematic Review and a Call for Action. Thrombosis and Haemostasis, 103, 271-276. https://doi.org/10.1160/TH09-09-0626

[56] Ageno, W., Cattaneo, R., Manfredi, E., Chelazzi, P., Venco, L., Ghirarduzzi, A., et al. (2010) Parnaparin versus Aspirin in the Treatment of Retinal Vein Occlusion. A Randomized, Double Blind, Controlled Study. Thrombosis Research, 125, 137-141. https://doi.org/10.1016/j.thromres.2009.05.007

[57] Hayreh, S.S., Podhajsky, P.A. and Zimmerman, M.B. (2011) Central and hemiCentral Retinal Vein Occlusion: Role of Anti-Platelet Aggregation Agents and Anticoagulants. Ophthalmology, 118, 1603-1611. https://doi.org/10.1016/j.ophtha.2011.04.036

[58] Brown, D.M., Campochiaro, P.A., Bhisitkul, R.B., Ho, A.C., Gray, S., Saroj, N., et al. (2011) Sustained Benefits from Ranibizumab for Macular Edema Following Branch Retinal Vein Occlusion: 12-Month Outcomes of a Phase III Study. Ophthalmology, 118, 1594-1602. https://doi.org/10.1016/j.ophtha.2011.02.022 